\section{Formalization of artisanal and small-scale mining in Colombia: Achievements and challenges relating to the attainment of Sustainable Development Goals}

\author{
Leonardo Güiza Suárez $^{1 *}{ }^{\oplus}$, Carlos Cante Puentes ${ }^{1 \odot}$ \\ y Lina Correa Muñoz ${ }^{1 \oplus}$
}

Formalización de la

minería en pequeña escala en Colombia: logros y desafíos en relación con los Objetivos de Desarrollo Sostenible

1 Universidad del Rosario. Bogotá, Colombia.

\section{SOUTH} SUSTAINABILITY

Cite as: Güiza, L., Cante, C. y Correa, L. (2021). «Formalization of artisanal and small-scale mining in Colombia: Achievements and challenges relating to the attainment of the Sustainable Development Goals». South Sustainability, 2(1), e028. doi: https://doi.org/10.21142/SS-02012021-e028

Article received: 26/10/2020 Peer review

Article approved: 5/1/2021

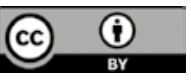

(c) The authors, 2021. Published by Universidad Científica del Sur (Lima, Peru)

* Corresponding author email: leonardo.guiza@urosario.edu.co

\begin{abstract}
Debates on artisanal and small-scale mining (ASM) and Sustainable Development Goals (SDGs) have mostly centered on the potential to alleviate poverty. However, the role of ASM in meeting other SDGs has received less attention within the literature. In addition, the literature has tended to focus on the failures of attempts to formalize ASM. In this paper, we identify seven concrete policy tools or mechanisms aimed at facilitating the process of formalizing ASM operators that have been in effect since 2014 in Colombia, and we assess to what extent they have contributed to meeting SDGs. Our study therefore diverges from recent literature which has mainly sought to explain the failures of efforts to formalize ASM. Instead, we show how mining formalization policies have contributed to the fulfillment of SDGs other than poverty alleviation, such as sustainable economic growth, peace, justice, strong institutions and good health. The importance of these practical legal mechanisms lies in their contribution to the creation of social and economic conditions that support the independence and sustainability of the ASM formalization process in Colombia, without requiring intervention from specific foreign agencies.
\end{abstract}

Keywords: Sustainability, artisanal and small-scale mining (ASM), mining formalization, Colombia, Sustainable Development Goals

\section{RESUMEN}

Los debates en torno a los Objetivos de Desarrollo Sostenible (ODS), por un lado, y la minería artesanal y en pequeña escala (MAPE), por otro, se han centrado principalmente en el potencial de esta última para aliviar la pobreza. Sin embargo, su papel en el cumplimiento de otros ODS ha recibido menos atención dentro de la literatura académica. Además, esta literatura se ha centrado en los intentos fallidos de formalización de la MAPE. En este artículo de revisión identificamos siete herramientas o mecanismos concretos de política pública destinados a facilitar el proceso de formalización de la MAPE vigentes desde 2014 en Colombia y evaluamos en qué medida han contribuido al cumplimiento de los ODS. Nuestro estudio, por lo tanto, difiere de la literatura reciente, que ha tratado de explicar los intentos fallidos de formalización de la ASM. Al contrario, mostramos cómo las políticas de formalización minera han contribuido al cumplimiento de ODS distintos al alivio de la pobreza, como el crecimiento económico sostenible; la paz, justicia e instituciones fuertes; y la buena salud. La importancia de estos mecanismos legales y prácticos radica en su contribución a la creación de condiciones sociales y económicas que apoyen la independencia y sostenibilidad del proceso de formalización de la MAPE en Colombia, sin requerir la intervención de agencias extranjeras específicas.

Palabras clave: sostenibilidad, minería artesanal y en pequeña escala (ASM), formalización minera, Colombia, Objetivos de Desarrollo Sostenible 


\section{Introduction}

Artisanal and small-scale mining (ASM) is traditionally defined as a low-tech, manually driven and labor-intensive activity, entailing a low degree of mechanization and initial investment. Low levels of environmental and safety awareness are also characteristic features of this type of mining (Hilson, 2002; Hilson and Maconachie, 2017; Schure, Ingram, Tieguhong and Ndikumagenge, 2011). Globally, ASM, which is minimally regulated and poorly organized (Bansah, 2019), contributes to mercury pollution (Siegel and Veiga, 2009). Studies have also shown that ASM communities are highly heterogeneous in terms of their composition, motivation and organizational structures (Hilson and Maconachie, 2017; Verbrugge, 2015).

Given its informal character, ASM's contribution to economic development is difficult to measure (Zvarivadza and Nhleko, 2018). Nevertheless, scholars concur that ASM constitutes a source of income and livelihood for rural populations in developing countries (Bansah, Dumakor-Dupey, Kansake, Assan and Bekui, 2018; Hentschel, Hruschka and Priester, 2003; Hilson, 2002; Schure et al., 2011).

There is also broad agreement that ASM should be formalized (Hilson, Goumandakoye and Diallo, 2019; Hilson and Maconachie, 2017), given that formalization policies enable this type of mining to be directed toward achieving sustainable development goals (SDGs). Three key concerns have traditionally been highlighted: the environment, health and safety (Hilson, 2002). Indeed, debate centered on ASM and SDGs tends to revolve around ASM's potential to alleviate poverty and to foster incomegenerating opportunities (Alliance for Responsible Mining [ARM], 2013; Labonne, 2014)., while its role in fulfilling other SDGs has received less attention.

In addition, there has been a tendency to focus on the reasons why formalization attempts fail. For instance, it has been reported that the failure of formalization policies can be attributed to the preference for largescale mining (Hilson et al., 2019; Siwale and Siwale, 2017) and the failure to understand and address the needs and dynamics of artisanal and small-scale miners (Hilson and Hilson, 2015). In this regard, few attempts have been made to document positive experiences.

In this paper, we examine concrete formalization tecdhniques that have been applied recently in Colombia and the extent to which they have contributed to SDGs for the period 2014-2019. In doing so, we diverge from the recent literature that has largely sought to explain the failure of attempts to formalize ASM (Hilson et al., 2019; Hilson and Hilson, 2015; Siwale an Siwale, 2017). A significant number of studies in this field have considered ASM solely as a poverty alleviation mechanism, and as a consequence they have failed to relate ASM to other SDGs, such as sustainable economic growth, peace, justice, strong institutions and good health. Our goal is to offer a contribution in this regard. Finally, we focus on an issue that has generally received little attention within academic study, namely the relationship between largescale mining and ASM (Rosales, 2019).

We begin by describing the social, economic and technical characteristics of ASM in Colombia. Next, we outline the main components of the Colombian mining formalization policy. We then introduce a series of policy mechanisms aimed at formalizing ASM in Colombia and their outcomes to date, analyzing the extent to which these mechanisms have the potential to contribute to the achievement of SDGs. Finally, we discuss our findings and derive conclusions from them.

\section{Artisanal and Small-Scale Mining (ASM) in Colombia}

Most Colombian mines comprise small-scale and artisanal production units. According to the results of Colombia's mining census (Ministerio de Minas y Energía/ Ministry of Mines and Energy [MME], 2012), 10,384 out of 14,357 mining production units (UPM in Spanish) in the country -that is, $72 \%$ - are small units. Large-scale mining accounts for only around $1 \%$ of mining operations in Colombia (MME, 2012). Indeed, $72.3 \%$ of mines in Colombia have fewer than six employees (MME, 2012), while only $37 \%$ of such mines are titled. Mechanization levels in most UPMs are low, with manual labor constituting the principal production factor (MME, 2019). The departments (Colombia's political and administrative subdivisions) with the largest number of small-scale mining units are Boyacá (2,024 mines), Antioquia (1,395 mines), Bolívar (967 mines) and Santander (954 mines) (MME, 2012).

ASM operations are usually engaged in by local communities (as opposed to large mining companies) in outlying rural areas where unemployment rates are high, and to which government institutions have little or no access (Veiga and Marshall, 2019). Most artisanal and small-scale miners possess low levels of education, with $71 \%$ of miners either illiterate or having only completed elementary education (MME, 2012). Colombian smallscale miners possess a rudimentary knowledge of mining resources and reserves in the areas where they operate. Furthermore, they engage in limited planning and conduct labor-intensive work, entailing high production costs and the use of unreliable technology (MME, 2019).

Most small-scale mining operations in Colombia, as in many other countries, are conducted informally (Echavarria, 2014). Of the country's UPMs (14,357 in total), $63 \%$ do not possess legal permits (or mining concessions) issued by the MME (MME, 2012) and only $35 \%$ of units pay royalties to the Colombian government. Most mines in Colombia do not even maintain inventories or accounting systems. An informal mine usually employs 
an average of three miners, each of whom earns around 1.2 times the minimum wage (Güiza, 2013). Safety, hygiene and occupational health measures are absent in $72 \%$ of Colombia's UPMs (MME, 2012). In addition, 18.8 $\%$ of miners in Colombia are not insured under the social security system, and $55 \%$ do not have formal employment contracts (Echavarria, 2014).

The continuing high rates of unemployment in developing countries and the current high price of gold on international markets are factors driving the high proportion of informal miners in Colombia (Veiga and Marshall, 2019). Of all the small-scale UPMs in the country, the percentage of illegal units is highest for gold mines (86 \%) (Güiza, 2013). It is estimated that sixty-six percent of small mines in Colombia are illegal (Güiza, 2013), while a tradition of informal mining is known to exist in $44 \%$ of Colombia's 1,122 municipalities (Veiga and Marshall, 2019).

\section{Colombia's mining formalization policy: From legalization to formalization}

For many decades, ASM activities could be legally conducted in Colombia in the absence of a mining title. In 1994, a first attempt was made to formalize smallscale mining in the country, under Law 141, which was subsequently reinforced in 2001 by the Mining Code (Law 685), which stipulated that a mining permit (either a mining title or a mining concession contract) was required for the exploration and exploitation of mining areas. However, mineral-rich areas have long been inhabited by communities engaged in traditional ASM, and for whom ASM has provided a source of income for decades or even centuries. The conditions for obtaining a mining title laid down in the Mining Code are stringent and are often out of reach for traditional communities characterized by low educational levels, high rates of poverty and unmet basic needs, as well as the minimal presence of state institutions (Echavarria, 2014).

Whentheminingauthorities in Colombiabegancreating concession contracts with large mining companies, from 2001, they neglected or overlooked communities that depended on subsistence mining for their livelihoods and which traditionally inhabited areas now granted to large companies. In 2015, under the Mining Code and through Law 1753, differential mechanisms were incorporated for small-scale miners' access to mining titles based on production scale (subsistence, small, medium and large scale mining), preventing any real possibility of ASM legalization. In other words, there was a rapid expansion of mining titles which did not acknowledge the needs of artisanal and small-scale miners (Echavarria, 2014; Pardo, 2013). This factor, combined with cumbersome governmental procedures that led to delays in responding to requests for legalization, and to incomplete legalization programs, generated multiple conflicts between smallscale and large mining entities (MME, 2019).
Because artisanal and small-scale miners can barely afford the costs associated with formalization (Echavarria, 2014), the Colombian government has taken a different stand. Essentially, the goal of the current formalization policy continues to be to ensure that all UPMs operate under legal mining titles and fulfill all mandated technical, social and legal requirements. In recent years, there has been an institutional shift in the framework used for understanding and addressing mining-related issues in Colombia, particularly with regard to artisanal and small-scale gold mining. From 2015 to 2019, the Colombian government acknowledged that it was unrealistic to expect artisanal and small miners to meet the legalization criteria for mining activities. Therefore, a differentiated approach toward ASM was developed and implemented. Thus, policy goals are no longer restricted to compliance with a legal procedure or the regularization of behavior; rather, the aim is to create the necessary legal and economic conditions conducive to the self-generating of such regularization.

Because legal restrictions and bans have proven unsuccessful when it comes to regulating ASM (Bansah, 2019), the Colombian formalization policy goes beyond the merely legislative. Considered from this alternative perspective, legalization is merely one aspect of the formalization approach (United Nations Environment Program [UNEP], 2012). That is to say, the formalization of mining not only relates to the granting of mining rights or titles to small-scale miners: in addition, this approach encompasses the creation of enduring conditions that facilitate access to funding, the introduction of efficient and clean technologies, the provision of training and education for small-scale miners and their families, and access to the national health and social security programs (Ministerio de Minas y Energía, 2019).

The emphasis in the mining formalization approach has traditionally been on recognition of miners' rights (Siegel and Veiga, 2009). In the Colombian case, this is an important consideration, given the particularities of ASM within the country. Colombia has endured an armed conflict for more than 50 years, and many artisanal and small-scale miners have suffered its consequences. Indeed, armed groups have penetrated into the mining sector through extortion, control of supplies, the marketing of minerals and other means, resulting in the widespread criminalization of ASM.

At the same time, many mining populations are composed of indigenous peoples and communities who are the descendants of enslaved Africans who have worked as miners over the centuries (Echavarria, 2014). Such communities engage in traditional mining, understood as mining exploitation units that lack mining titles and which fulfill two requirements: firstly, that they were established at least a decade prior to the 2010 Act 1382 (Decree 2715, 2010); and secondly, that mining activities 
have been engaged in continuously for at least five years (Güiza, 2013). Around 40 \% of Colombia's small mines can be categorized as traditional mining units (Güiza, 2013). Thus, a substantial number of artisanal and small-scale miners are considered «victims of conflicts over natural resources» (Echavarria, 2014, p. 20) under the recent formalization policy. Furthermore, according to the MME (2012) $10 \%$ of miners self-identify as members of ethnic communities.

To summarize, what distinguishes the Colombian Mining Formalization Policy from previous legislation is its intended focus on the creation of enduring legal, economic and social conditions that facilitate the legalization of small-scale mining as a process that can evolve freely. A question that arises is: how are such conditions created and how can they be linked to SDGs? To address these questions, we now turn to the specific legal, environmental and social mechanisms designed to facilitate the formalization of ASM operators.

\section{Findings and Discussion}

We will now examine seven legal, environmental and social mechanisms aimed at facilitating the formalization of ASM operators in Colombia. Firstly, we will describe them, identifying their characteristics, then we will outline the main outcomes to date, and finally we will highlight their achievements in relation to SDGs.

\section{Formalization Subcontracts}

Few studies have explored the relationship between large-scale mining and ASM (Rosales, 2019). However, Colombia constitutes an illustrative case study of attempts to strengthen this relationship. There have been multiple land occupation conflicts between title holders and traditional mining communities, usually comprising small-scale and artisanal miners. The MME has played the role of mediator in these conflicts, developing mechanisms for promoting dialogue and negotiation between the parties concerned (MME, 2014). The aim is not only to build trust among the parties, but also to facilitate the development of lasting and profitable agreements (MME, 2014).

The MME has mediated conflicts between small-scale miners and large mining companies by encouraging and developing dialogue and alternative dispute-resolution mechanisms between the parties concerned. Between January 2016 and May 2019, the MME implemented a total of 536 negotiation processes (MME, 2019), most of which occurred in the department of Antioquia, where the majority of Colombia's UPMs are located. Since the signing of the peace agreement between the Colombian government and the FARC (Revolutionary Armed Forces of Colombia) in November 2016, there has been a significant increase in such dialogue.
The mechanism of formalization subcontracts promotes the coexistence of both types of mining entities. Formalization subcontracts are a legal tool enabling the regulating of the conditions under which small-scale miners can exploit areas that were previously granted to the holders of an existing legal mining title (MME, 2014). A signed subcontract relating to mining operations is not equivalent to a mining title.

These subcontracts, authorized by the MME, are agreements made between the holders of an existing mining title and small-scale miners, enabling the latter to exploit areas already granted to the former. The obtaining of signed formalization subcontracts enables ASM operators to conduct their mining activities legally under an authorized mining title, thereby facilitating their compliance with administrative mining procedures. In other words, possession of a subcontract enables the transition from informality to formality. Whereas in traditional mining contracts the titleholder assumes technical, operational and environmental responsibility, under formalization subcontracts these responsibilities lie with the subcontractor (i.e., the ASM association). Formalization subcontracts incentivize large mining companies by allowing them to exploit resources through subcontracts during the mining exploration stage. Formalized subcontracts are valid initially for at least four years, but can be extended.

Formalization subcontracts serve as a protective barrier, shielding small-scale miners from the prevailing, undifferentiated mining legislation, given that a formalization subcontract automatically suspends some of the legal sanctions that small-scale miners would otherwise face(i.e., those sanctions imposed on individuals who exploit areas for which they do not possess a mining title or an environmental license) (MME, 2019).

When exploiting an area that is regulated under a formalization subcontract, small-scale miners are required to implement the Mining and Environmental Guidelines issued by the Ministry of Environment and Sustainable Development. One important implication of this requirement is that the use of mercury (particularly in gold mining) by small-scale miners is prohibited. Consequently, operational subcontracts contribute to the ensuring of safe drinking water under SDG 6, which addresses issues associated with clean water and sanitation (United Nations, 2015). The ban on the use of mercury impacts positively on the protection of water ecosystems. Furthermore, the provision for training and technical counseling by large mining companies to small-scale miners, aimed at enhancing productivity and technological innovation, contributes to SDG 8 (decent work and economic growth).

Between 2016 and 2019, a total of 338 applications for subcontracts were received, following dialogue held 
between small-scale miners and large mining companies. So far, 108 formalization subcontracts in 10 Colombian departments have been approved by the MME, of which 65 were granted in Antioquia. As a result of the implementation of such subcontracts, 1,608 small-scale miners have now been granted legal status by government authorities (MME, 2019).

\section{Return of areas for mining formalization}

In addition to the subcontracting tool discussed above, the banking or repository of areas allocated for mining formalization is an instrument specifically designed to meet the needs of artisanal and small-scale miners. This legal mechanism is aimed at granting access to areas for mining exploration and exploitation to small-scale and artisanal miners. Its underlying purpose is to solve a practical problem. Usually, when mining titles expire or when the titleholders of mining rights relinquish their title, small-scale miners are unable to gain access to such untitled and unoccupied areas because of the array of requirements that they are expected to meet in order to be eligible for mining concessions. In such cases, the areas in question are generally granted to third parties (usually large companies), thus perpetuating ASM operators' inability to exploit such areas legally.

Under Decree 1949, dated November 28, 2017, unoccupied areas allocated for mining formalization can be held or «frozen» in a «bank» for such areas, and managed by the National Mining Agency (ANM in Spanish) for a period of up to two years. During this period, the relevant authorities verify whether there are any smallscale miners who may be interested in exploiting the areas now available for mining, and in seeking formalization. Subsequently, such zones, which are registered in the bank, can be restored to small miners through another mechanism entailing the return of areas for mining formalization. This is a legal mechanism whereby holders of titles to mining rights can relinquish control of certain zones that they do not wish to retain; in turn, through an administrative procedure these zones are granted by the ANM to small-scale miners for their use.

The beneficiaries of the returned areas may be small-scale miners operating in areas that have already been granted to third parties (such as existing largescale mining companies), as well as small-scale miners operating in areas other than those for which there is an existing mining title available for reallocation (MME, 2019).

Given the scarcity of areas for which a mining title can be granted in Colombia (because such areas were previously granted to third parties), the «banking» of areas and the returning of areas for mining formalization constitute legal mechanisms with the potential to deter a third party from requesting a mining title to such areas. These mechanisms support decent work and economic growth (SDG 8) by prioritizing and protecting the rights of ASM operators, who traditionally belong to marginalized and impoverished groups, to use land for mining purposes. Indeed, the return of areas for mining formalization entails not only the transfer of rights for the exploitation of areas, but also, most importantly, the provision of assistance and support by large-scale companies to smallscale miners, related to production techniques and the use of environmentally sustainable methods.

This mechanism of returning areas to small-scale miners also contributes to the process of monitoring the implementation of clean production technologies by the MME, thereby contributing to SDG 3 (good health and well-being).

Although the return of areas for mining formalization is a relatively recent initiative (under Decree 1949, dated November 28, 2017), progress in this area is also illustrated by the case of Mineros S.A. and EMIJON in the municipality of Zaragoza, Antioquia. This case involved the transfer of 127 hectares of land from a large-scale mining company, Mineros S.A., to the Empresa Minera de Jobo Medio S.A.S., comprising small-scale miners whose status at the time was informal. Six cases involving the return of areas for mining formalization were the result of the opening up of dialogue between small-scale miners and large mining companies from 2016 to 2019.

\section{Tailored technical assistance and differentiated inspection}

While the expansion of the formal system of property rights is a necessary component of any formalization process, the recent literature has shown that enhancement of these rights does not in itself end poverty (Siegel and Veiga, 2009). One reason for this is that the possession of legal titles does not necessarily imply access to resource benefits (Siwale and Siwale, 2017). The formalization of ASM must also include measures for preventing miners from withdrawing from the formalization program, in conjunction with legal and environmental restrictions (UNEP, 2012), particularly in the context of structured and differentiated monitoring and enforcement procedures (Bansah et al., 2018). The formalization approach, therefore, must be extended beyond a simple licensing system, incorporating a differentiated and inclusive inspection system.

Recognizing that capacity building is a key aspect of sustainable mining (Owusu, Bansah, and Mensah, 2019) and a major consideration in the formalization of ASM (Duff and Downs, 2019), the MME has established cooperation agreements with several environmental entities, development centers, universities and local government authorities, with the aim of improving the mining production of ASM operators. Several initiatives have been implemented, including measures such as providing technical assistance for the eradication of 
mercury (particularly in gold mining), enhancing practical mining skills, fostering miners' financial inclusion, and strengthening their entrepreneurial skills (MME, 2019).

The participation of diverse stakeholders is integral to ASM formalization (Dzimunya, Mapamba, Dembetembe, Dzwiti and Mukono, 2018). Important measures include the involvement of strategic partners who can support small-scale miners. To date, the following allies have been identified: the MME and its subordinate entities, international aid organizations, public and private universities, local environmental authorities (Corporaciones Autónomas Regionales), local government authorities, and the business and financial sectors (MME, 2019). Following a meeting attended by all the interested parties, partnerships were established aimed at strengthening small-scale mining. Technical assistance programs focusing on issues such as job safety and health, the formulating of mining work plans, ensuring compliance with environmental plans, providing access to banking and other financial services, and the payment of royalty fees, have also been implemented.

Following the categorization of a UPM, its specific needs are identified by the MME in order to facilitate the provision of tailored assistance, thereby contributing to SDG 8 (the creation of decent working conditions and economic growth). To date, technical assistance programs have been implemented in 1,567 UPMs, benefiting 14,276 small-scale miners across 17 Colombian departments (MME, 2019). In addition, 226 miners have received training in the creation of productive projects, while 310 miners have received training to enhance their employability (MME, 2019).

The National Policy for Mining Security (Política Nacional de Seguridad Minera), which was introduced in 2011, aims to improve miners' safety by preventing and reducing mining accidents and emergencies. The Colombian National Learning Service (SENA in Spanish) has assisted miners, enabling them to maximize their exploitation of mining sites while developing safe mining activities (MME, 2019). To date, following their participation in the Mining Formalization Program, 12,449 miners have received technical training in mining, environmental sustainability and entrepreneurial skills (MME, 2019). This approach involves the provision of training and education not only to small-scale miners, but also to local environmental entities, in order to ensure that public officials gain a deeper understanding of mining formalization procedures.

Along with training initiatives, a differential inspection tool has also been implemented. The underlying objective of this tool is to monitor ASM operators' compliance with basic technical standards. The goal of differentiated inspection, conducted by the ANM, is to provide miners with guidance aimed at improving their technical abilities, rather than penalize them for their informal mining practices.

Efforts have also been made to simplify governmental procedures and expedite formalities for those miners who are willing to be formalized while at the same time meeting social and environmental goals (UNEP, 2012). To this end, working groups have been established. These groups comprise various national and subnational government entities, such as the Ministry of Defense, the Department of Commercial Control of Weapons, Ammunition and Explosives, the Ministry of Environment and Sustainable Development, the National Tax and Customs Directorate, the Autonomous Regional Authorities and the Banco Agrario (the public sector bank that finances rural/agricultural activities in Colombia). Examples of the outcomes of these working groups include the manufacturing of explosives required to make mining activities more accessible to small-scale miners and the simplification of direct mineral export procedures.

\section{Demarcation of Special Reserve Areas}

As we have already mentioned, there are territories in Colombia that have been inhabited historically by traditional mining communities who face constraints when attempting to pursue the formalization route. To address this issue, another legal mechanism has been introduced, namely special reserve areas (ARE in Spanish). This mechanism enables traditional mining communities to obtain a legal mining title through a special concession agreement valid for 30 years and extendable for a further 30 years (MME, 2019). Although this mechanism was created in 2001 (Law 685), no significant progress was made in its implementation until 2016, when the concept of «mining communities» was reexamined and reformulated.

Once small-scale miners have declared their intention to participate in AREs, and once the areas have been properly demarcated by mining institutions, they are recorded in the Single Registry of Minerals Marketers (Registro Único de Comercializadores de Minerales, RUCOM), a platform established for the regulating and control of supply and marketing chains associated with mineral production. The information recorded and maintained through RUCOM facilitates the obtaining by miners of fairer and more competitive prices. In turn, this process contributes to the achieving of SDGs 1 and 8 (to end poverty and to promote sustained, inclusive and sustainable economic growth, full and productive employment, and decent work, United Nations, 2015). This is a transitional step towards formalization.

Once these special reserve areas have been officially designated as such, government agencies conduct geological and mining studies aimed at enhancing their utilization by traditional communities and the benefits 
obtained from their use. If evidence of mineral potential and economic feasibility is found in such zones, a special concession agreement is entered into by the government and the associated mining community. If no mineral potential is found, then a project is initiated with the aim of diverting labor within the mining community into alternative economic activities.

A lack of community engagement has been identified as a major impediment to the formalization of smallscale mining (Alves, Ferreira and Araujo, 2016). A focus on communities, as opposed to individuals, as the main beneficiaries of AREs serves to boost the creation of associative and cooperative structures that have been shown to play an important role in the mitigation of the social and environmental impacts of mining (Alves, Ferreira and Araújo, 2019).

The establishment of AREs also alleviates difficulties experienced by small-scale miners associated with meeting legal formalities, while expediting administrative procedures. For example, once an ARE has been demarcated as such by mining institutions, the ANM designs and conducts a mining-based geological study, the findings of which are shared with the traditional mining community associated with the area in question. Subsequently, these findings may serve as data for the development of a work plan (Planes de Trabajos y Obras, PTO).

The dialogue between small-scale miners and mining entities held between 2016 and 2019 prompted 195 requests for the demarcation of AREs. Currently, there are 109 AREs, across 22 departments in Colombia (MME, 2019). As a result of the demarcation of these areas, 2,714 miners have acquired legal status (MME, 2019). Furthermore, 359 requests to the MME for the demarcation of areas are currently pending. If approved, these requests could benefit another 2,729 small-scale miners (MME, 2019).

\section{Promoting responsible supply chains: Strengthening government control of the mining value chain}

Historically, Colombia's mining supply and marketing chain (particularly in the case of small-scale and artisanal gold mining) has largely been overlooked by government agencies. This lack of supervision has enabled armed groups to infiltrate the mineral production and distribution chains in order to finance their illegal activities (Massé and Munevar, 2016), and formal channels have been routinely used to legalize illegally produced minerals (particularly gold).

A series of decisions have sought to boost the trade in «conflict-free» minerals in Colombia. RUCOM, which was launched in 2015, has made significant progress in this regard. RUCOM is an online registry containing information concerning those actors who are legally authorized to market and sell minerals in Colombia, including, for example, marketers of minerals, holders of mining rights and jewelry manufacturers. Its goal is to promote greater transparency and effective monitoring of the supply chain and marketing practices relating to minerals in Colombia (Massé and Munevar, 2016). RUCOM also facilitates improved documentation of gold subsistence mining, thereby contributing to greater regulation not only of artisanal and small-scale miners, but also of intermediaries within the value chain.

For example, in the past, it was often the case that barequeros (micro-scale artisans who produce minimal quantities of gold) would report the production of large quantities of gold beyond their technical capacities (1 kg of gold or more each month). Clearly, a significant proportion of the gold purportedly being produced by barequeros was actually derived from illegal sources. In fact, it was discovered that some marketers had been posing as barequeros, using their IDs to legalize illegally produced gold. More effective regulation of the marketing and distribution of minerals has included the establishing of ceilings on the amounts that barequeros can market and sell.

Although RUCOM is a mechanism oriented towards law enforcement, ASM operators receive special treatment as long as they are registered in formalization programs. Thus, operators who are permitted to engage in the mineral trade include not only legal title holders, but also informal miners registered in formalization programs, as well as subsistence miners (Massé and Munevar, 2016).

To register with the RUCOM platform, miners are required to provide tax certificates, financial statements and other documentation (Massé and Munevar, 2016). However, efforts to ensure that miners are registered and mining activities are monitored via the RUCOM platform extend beyond the purposes of taxation; they constitute significant steps toward the implementation of the OECD Due Diligence Guidance for Responsible Mineral Supply Chains (OECD, 2016). At the same time, registering and taxing informal work goes hand in hand with expanding the legal and social protection system (Chen, 2012).

Through its positive role in protecting human rights and reducing violence and illicit financial and arms channels, RUCOM contributes to SDG 16 (peace, justice and strong institutions - United Nations, 2015). Furthermore, by promoting crime-free mineral value chains, it ensures responsible consumption and production (SDG 12). To date, 1,718 AREs and 152 formalization subcontracts have been registered on the RUCOM platform, and 80,656 subsistence miners are registered with RUCOM and authorized to exploit minerals (Agencia Nacional de Minería, ANM, 2019).

\section{Access to funding}

Small-scale mining in Colombia has traditionally been constrained by lack of access to funding. This constraint imposes limitations for miners with regard to paying 
employees and suppliers, trading minerals and investing in technology. It has been estimated that $64 \%$ of mining enterprises in Colombia pay their workers in cash (MME, 2012).

A possible reason for the disassociation of the financial sector and small-scale mining could be related to a widespread perception within financial institutions that small-scale mining entails a high risk of money laundering (InSight Crime, 2019; Pardo, 2013). Indeed, mining (and especially gold mining), along with drug trafficking, is a major source of funding for illegal armed groups in Colombia (Echavarria, 2014). These groups are engaged in extortion, direct exploitation of minerals and money laundering (Defensoría del Pueblo de Colombia, 2017; den Held, 2019; Massé and Le Billon, 2018; Massé and Munevar, 2016). Small-scale mining is also regarded by financial institutions as a high-risk activity because of the volatility of mineral markets (MME, 2019). Another factor that could help to explain this disassociation is a lack of awareness regarding existing banking services among many small-scale miners, or a lack of the assets required as security for the acquiring of credit among those who are aware of the services available.

Access to land facilitates access to capital (Siegel adn Veiga, 2009) and to markets (UNEP, 2012), which accounts for the emergence of land access mechanisms, as previously described. In addition, separate funding channels have been created to address this situation and provide small-scale miners with access to financial resources. An agreement forged between the MME and the Banco Agrario de Colombia resulted in the creation of an institutionalized funding channel for small-scale miners throughout the country. As of 2019, 23 loans had been approved by the Colombian mining authority, amounting to COP\$6,938,650,000 million (around US\$2,019,397), most of which are intended to finance coal and mine building materials.

The investment project «Generación de Condiciones Favorables de Acceso al Sistema Financiero para la Pequeña Minería a Nivel Nacional, vigencia 2019-2021» comprises multiple components aimed at achieving the following objectives: (1) to support small-scale miners in the design of bankable projects and to advise them on how to ensure the technical viability of such projects, (2) to strengthen financial literacy and entrepreneurial skills within smallscale mining communities, (3) to lower the costs of providing credit to small-scale miners incurred by financial institutions through the implementation of an interest rate hedging instrument, in order to reduce interest rates by three percentage points, and (4) to regulate and monitor funded projects (MME, 2019).

The provision of access to funding enables small-scale miners to improve their economic and working conditions. In turn, these improvements promote poverty alleviation, thereby contributing significantly to the achievement of SDGs 1 and 8, which are, respectively, no poverty and decent work and economic growth.

\section{Mining and Environmental Guidelines and the Single National Mercury Plan}

A key concern relating to ASMs is their environmental impact, particularly mercury released by ASM gold mining (Hilson, Hilson and Pardie, 2007). Small-scale or artisanal miners wishing to formalize their activities were traditionally required to conduct environmental impact assessments by the relevant government agencies. However, the conducting of environmental assessments required significant investment in terms of money, time and effort well beyond the reach and organizational capabilities of ASM operators. In addition, miners were required to suspend their mining activities until they succeeded in securing the respective environmental licenses. Ultimately, it was acknowledged that asking large-, medium-, small-scale and artisanal miners to fulfill uniform requirements for obtaining formal environmental permits was unrealistic and untenable.

The Mining and Environmental Guidelines were created in order to provide a more differentiated approach to formalization during the exploration stage. Developed jointly by the MME and the Ministry of Environment and Sustainable Development, these guidelines serve as a tool enabling small-scale and artisanal miners to improve their mining operations and implement effective environmental management of their operations. What is particularly significant about this consultative tool is that its regulatory mechanisms are less stringent than those applicable to large mining companies. Also, by following the guidelines, small-scale and artisanal miners can continue to engage in mining activities while still in the process of becoming formalized. In other words, ASM operators who implement the guidelines are not obliged to suspend the mining activities which are the primary means of subsistence for their families.

In 2014, a series of procedures and regulations were consolidated into the Single National Mercury Plan (Plan Único Nacional de Mercurio). This plan comprises four key components: institutional strengthening, management strategies, education and communication, and knowledge management and applied research (MME, 2019). Institutional strengthening has led to the upgrading and monitoring of 968 UPMs as formalized units, as well as the design and implementation of 14 action plans for halting the use of mercury (MME, 2019). Changes in management strategies have been implemented in 76 mining plants (across nine departments), benefiting 1,112 small-scale miners. These interventions have led to an estimated annual reduction of 7.3 tons of mercury consumption (MME, 2019). Furthermore, they have facilitated miners' access to funding for technological upgrading, through the Banco Agrario de Colombia. 
Approaching mercury usage from the perspective of sustainability involves focusing not only on the banning of mercury use (ARM, 2013) but also on the provision of relevant training and educational programs. Implementation of the education and communication components of the Plan has resulted in the provision of training to 42,678 artisanal miners (across 14 Colombian departments) regarding best practices relating to clean extraction and production techniques (MME, 2019). For example, small-scale miners have been provided with portable metallic gutters that are easy to carry, enabling the recovery of increased quantities of gold. Significantly, they are made from aluminum, thereby ensuring that miners will not use mercury, which corrodes aluminum (MME, 2019). Educational and communication strategies have included the organizing of training workshops on clean technologies as well as events for the dissemination of technologies (10 events have been organized across nine departments, resulting in the certification of a total of 292 miners). At the same time, 12,157 miners have received training in environmentally sustainable mining best practices (MME, 2019).

Environmental guidelines and training and education programs are designed to safeguard human health and mitigate the environmental impacts of mining activities, thereby contributing to SDG 3 (good health and wellbeing). It is estimated that mercury usage will decrease annually by 81.67 tons as a result of these educational and communication programs (MME, 2019). In addition, knowledge management strategies have led to the creation of guidelines for mercury-free gold recovery. In total, 10 sets of guidelines have been developed, each of which is based on the characteristics of particular types of mining deposits occurring in eight departments within Colombia (Antioquia, Bolívar, Cauca, Risaralda, Caldas, Córdoba, Nariño and Huila) (MME, 2019). Best practices relating to the treatment and disposal of tailings have also been promoted (MME, 2019).

\section{Conclusion}

In this paper we have described and analyzed seven policy techniques that have been implemented recently within the Colombian mining formalization sector, demonstrating the extent to which they have contributed to the meeting of SDGs.

As we have already noted, one of the main differences between the legalization and formalization approaches is that the latter encourages the coexistence of smallscale and large-scale mining entities. This strategy of coexistence is fostered through the creation of incentives for large mining companies and small-scale mining enterprises to work together. For example, the formalization of subcontracts promotes the coexistence of both types of mining entities. Given the limited availability of areas where mining titles can be granted in Colombia, the expansion of the property rights system has been a key driver of the formalization approach in terms of poverty alleviation. Furthermore, strategies involving the "banking» and returning of areas for mining formalization have not only facilitated access to formal ownership; they also have the potential to contribute to the improved health and well-being of ASM operators.

The literature reveals a consensus regarding the necessity of extending the formalizing of mining beyond the creation of a licensing system to encompass a differentiated but inclusive inspection process. The acquisition of mineral rights does not imply that the perceived benefits of formalization have actually been obtained. Mining formalization policies have mostly failed because the emphasis has been on formalization procedures that impose a heavy burden on miners, rather than prioritizing the protections and benefits associated with formalization. In response to this challenge, Colombia's mining formalization policy has established land use rights in conjunction with other associated measures, such as capacity building, technical assistance programs and a national mine safety policy. In turn, these measures promote inclusive and sustainable economic growth.

The establishment of Special Reserve Areas not only aids the expediting of administrative procedures and the alleviating of difficulties associated with meeting legal formalities encountered by small-scale miners; it also encourages the creation of ASM associative and cooperative structures. Such structures have been shown to play an important role in the mitigation of the social and environmental impacts of mining. Strengthening government control of the mining value chain through the online RUCOM platform has the potential to protect human rights and reduce violence and illicit financial channels, contributing to more responsible consumption and production. By easing access to capital and markets, funding channels have the potential to alleviate poverty and to create decent work and economic growth. Finally, the environmental guidelines and training and educational programs that have been implemented recently safeguard human health and mitigate the negative environmental impacts of mining activities.

The importance of these practical legal mechanisms lies in their role in facilitating the creation of social and economic conditions for the independent and sustained existence of ASM formalization in Colombia, without requiring the intervention of specific foreign agencies. In other words, formalization not only implies the obtaining of mining rights or a mining title, but also miners' increased engagement with a social and economic context that provides them with tools to enable them to engage in their mining activities sustainably. By contrast, the recent literature has indicated that attempts to formalize ASM in other countries have focused on meeting immediate needs, rather than on a planning process. 
Historically, illegal armed groups have been involved in extortion, direct exploitation of minerals and money laundering in Colombia. This phenomenon has led to the criminalization of ASM. The formalization approach has been effective in decriminalizing the informal mining sector in Colombia, by acknowledging that ASM operators comprise communities of individuals with particular needs, and by addressing those needs.

While progress has been made, difficulties persist. For example, the mining formalization policy in Colombia remains centralized, and the centralization of natural resource governance has been found to constrain the formalization of ASM.

This paper has demonstrated the extent to which formalization policies remain integral to the sustainable development of ASM enterprises. Given the range of

\section{Bibliographic references}

Alliance for Responsible Mining, ARM. (2013). Approaching artisanal and small-scale mining through the lens of human rights: A call for international action. Available from: http://www.responsiblemines. org/wp- content/uploads/2018/05/059 Human Rights_and_ASM full-version.pdf

Alves, W., Ferreira, P. and Araujo, M. (2016). «Sustainability in the Brazilian mining sector: Barriers and interventions to overcome». Conference: XXXVI Encontro Nacional de Engenharia de Producão, João Pessoa, 2016.

Alves, W., Ferreira, P. and Araújo, M. (2019). «Mining co-operatives: A model to establish a network for sustainability». Journal of Co-operative Organization and Management, 7(1), pp. 51-63. doi:10.1016/j.jcom.2019.03.004

Agencia Nacional de Minería, ANM. (2019). Datos abiertos. Bogotá: ANM. Available from: https://www.anm.gov.co/?q=Datos Abiertos_ANM

Bansah, K. J. (2019). «From diurnal to nocturnal: Surviving in a chaotic artisanal and small-scale mining sector». Resources Policy, 64, 101475. Available from: https://doi.org/10.1016/j.resourpol.2019.101475

Bansah, K. J., Dumakor-Dupey, N. K., Kansake, B. A., Assan, E. and Bekui, P. (2018). «Socioeconomic and environmental assessment of informal artisanal and small-scale mining in Ghana». Journal of Cleaner Production, 202, pp. 465-475. Available from: https://doi. org/10.1016/j.jclepro.2018.08.150

Chen, M. (2012). «The informal economy: Definitions, theories and policies». Available from: http://www.wiego.org/sites/default/ files/publications/files/Chen_WIEGO_WP1.pdf

Defensoría del Pueblo de Colombia. (2017). Las amenazas y las extorsiones: Desafío a la paz territorial. Bogotá: Defensoría del Pueblo de Colombia.

den Held, D. (2019). «En el triángulo de Telembí en Colombia grupos irregulares explotan a mineros ilegales». InSight Crime. Available from: https://es.insightcrime.org/noticias/noticias-del-dia/enremoto-triangulo-de-telembi-en-colombia-pandillas-explotanmineros-ilegales/ dynamics stemming from the differences inherent in the geographical locations of ASM enterprises, no generalized solution can be recommended for addressing all of the problems being faced. Nevertheless, we hope that these tools and mechanisms will prove useful in the development of formalization policies in other countries.

\section{Funding}

The research was self-funded.

\section{Authors' contributions}

The authors contributed equally to the paper.

\section{Competing interests}

The authors declare no conflicts of interest.

Duff, P. M. and Downs, T. J. (2019). «Frontline narratives on sustainable development challenges/opportunities in the 'illegal' gold mining region of Madre de Dios, Peru: Informing an integrative collaborative response». The Extractive Industries and Society, 6(2), pp. 552-561. Available from: https://doi.org/10.1016/j.exis.2019.01.005

Dzimunya, N., Mapamba, L., Dembetembe, G., Dzwiti, K. and Mukono, T. (2018). «Formalization of a roadmap to maximize the contribution of artisanal and small-scale mining in Zimbabwe». SAIMM ASM Coference 2018: Fostering a regional approach to ASM transformation in sub-Saharan Africa, 2018, Johannesburg.

Echavarria, C. (2014). 'What is legal?' Formalising artisanal and smallscale mining in Colombia. London: International Institute for Environment and Development (IIED) and Alliance for Responsible Mining (ARM).

Güiza, L. (2013). «La pequeña minería en Colombia: una actividad no tan pequeña». Dyna, 80(181), pp. 109-117.

Hentschel, T., Hruschka, F. and Priester, M. (2003). Artisanal and smallscale mining: Challenges and opportunities. London: International Institute for Environment and Development, IIED.

Hilson, G. (2002). «Small-scale mining and its socio-economic impact in developing countries». Natural Resources Forum, 26(1), pp. 3-14.

Hilson, G., Goumandakoye, H. and Diallo, P. (2019). «Formalizing artisanal mining 'spaces' in rural sub-Saharan Africa: The case of Niger». Land Use Policy, 80, pp. 259-268. Available from: https://doi. org/10.1016/j.landusepol.2018.09.023

Hilson, G. and Hilson, A. (2015). «Entrepreneurship, poverty and sustainability. Critical reflections on the formalisation of smallscale mining in Ghana». Available from: https://www.theigc.org/ wp-content/uploads/2015/04/Hilson-Hilson-2015-Working-Paper. pdf

Hilson, G., Hilson, C. J. and Pardie, S. (2007). «Improving awareness of mercury pollution in small-scale gold mining communities: Challenges and ways forward in rural Ghana». Environmental Research, 103(2), pp. 275-287. Available from: https://doi. org/10.1016/j.envres.2006.09.010 
Hilson, G. and Maconachie, R. (2017). «Formalising artisanal and small-scale mining: Insights, contestations and clarifications». Area, 49(4), pp. 443-451. Available from: https://doi:10.1111/area.12328

InSight Crime. (2019). «Empresarios de oro de Colombia usaron mineros falsos y muertos para lavar dinero». InSight Crime. Available from: https://es.insightcrime.org/noticias/analisis/empresarios-de-orode-colombia-usaron-mineros-falsos-y-muertos-para-lavar-dinero/

Labonne, B. (2014). «Who is afraid of artisanal and small-scale mining (ASM)?». The Extractive Industries and Society, 1(2), pp. 121-123. Available from: https://doi:10.1016/j.exis.2014.03.002

Ledwaba, P. (2017). «The status of artisanal and small-scale mining sector in South Africa: Tracking progress». Journal of the Southern African Institute of Mining and Metallurgy, 117(1), pp. 33-40. Available from: https://doi:10.17159/2411-9717/2017/v117n1a6

Massé, F. and Le Billon, P. (2018). «Gold mining in Colombia, postwar crime and the peace agreement with the FARC». Third World Thematics: A TWQ Journal, 3(1), 116-134. Available from: https://doi $: 10.1080 / 23802014.2017 .1362322$

Massé, F. and Munevar, J. (2016). Due diligence in Colombia's gold supply chain. OECD. Available from: https://www.academia. edu/26077299/Due_diligence in_Colombias gold_supply_chain

Ministerio de Minas y Energía, MME. (2012). Censo Minero Departamental 2010-2011. Bogotá: Ministerio de Minas y Energía.

Ministerio de Minas y Energía, MME. (2014). Política nacional para la formalización de la Minería en Colombia.

Ministerio de Minas y Energía, MME. (2019). Formalización minera. Un camino más allá de la legalidad. Bogotá: Dirección de Formalización Minera.

OECD. (2016). OECD Due Diligence Guidance for Responsible Supply Chains of Minerals from Conflict-Affected and High-Risk Areas: Third Edition. Paris.

Owusu, O., Bansah, K. J. and Mensah, A. K. (2019). «"Small in size, but big in impact": Socio-environmental reforms for sustainable artisanal and small-scale mining». Journal of Sustainable Mining, 18(1), pp. 3844. Available from: https://doi.org/10.1016/j.jsm.2019.02.001

Pantoja, F. and Pantoja, S. (2016). «Problemas y desafíos de la minería de oro artesanal y en pequeña escala en Colombia». Revista Facultad de Ciencias Económicas, 24(2), pp. 147-160. Available from: https:// doi.org/10.18359/rfce.2217

Pardo, L. (2013). «La conflictividad por el territorio, el control de los RRNN y la renta minera: El choque de las locomotoras mineras en Colombia». In: Gray, L. (Ed.), Minería en Colombia: Institucionalidad y territorio, paradojas y conflicto. Bogotá: Contraloría General de la República.
Rosales, A. (2019). «Statization and denationalization dynamics in Venezuela's artisanal and small scale-large-scale mining interface». Resources Policy, 63, 101422. Available from: https://doi. org/10.1016/j.resourpol.2019.101422

Schure, J., Ingram, V., Tieguhong, J. C. and Ndikumagenge, C. (2011). «ls the god of diamonds alone? The role of institutions in artisanal mining in forest landscapes, Congo Basin». Resources Policy, 36(4), pp. 363-371. Available from: https://doi.org/10.1016/j. resourpol.2011.09.002

Siegel, S. and Veiga, M. (2009). "Artisanal and small-scale mining as an extralegal economy: De Soto and the redefinition of "formalization"». Resources Policy, 34(1), pp. 51-56. Available from: https://doi.org/10.1016/j.resourpol.2008.02.001

Siwale, A. and Siwale, T. (2017). "Has the promise of formalizing artisanal and small-scale mining (ASM) failed? The case of Zambia». The Extractive Industries and Society, 4(1), pp. 191-201. Available from: https://doi.org/10.1016/j.exis.2016.12.008

Spiegel, S. J. (2015). «Shifting formalization policies and recentralizing power: The case of Zimbabwe's artisanal gold mining sector». Society \& Natural Resources, 28(5), pp. 543-558. Available from: https://doi. org/10.1080/08941920.2015.1014606

United Nations. (2015). «Transforming our world: The 2030 agenda for sustainable development». Available from: https://sustainabledevelopment.un.org/content/ documents $/ 21252030 \% 20$ Agenda $\% 20$ for $\% 20$ Sustainable $\% 20$ Development\%20web.pdf

United Nations Environment Programme, UNEP. (2012). «Analysis of formalization approaches in the artisanal and small-scale gold mining sector based on experiences in Ecuador, Mongolia, Peru, Tanzania and Uganda». Available from: https://wedocs.unep.org/ bitstream/handle/20.500.11822/11357/Formalization_Document Final_June_2012.pdf? sequence $=1 \&$ isAllowed $=y$

Veiga, M. and Marshall, B. (2019). «The Colombian artisanal mining sector: Formalization is a heavy burden». The Extractive Industries and Society, 6(1), pp. 223-228. Available from: https://doi. $\operatorname{org} / 10.1016 /$ j.exis.2018.11.001.

Verbrugge, B. (2015). «The economic logic of persistent informality: Artisanal and small-scale mining in the Southern Philippines». Development and Change, 46(5), pp. 1023-1046. Available from: https://doi:10.1111/dech.12189

Zvarivadza, T. and Nhleko, A. S. (2018). «Resolving artisanal and small-scale mining challenges: Moving from conflict to cooperation for sustainability in mine planning». Resources Policy, 56, pp. 78-86. Available from: https://doi.org/10.1016/j.resourpol.2017.12.003 